\title{
The Evaluation Of Sales Promotion In Jakarta Retail Business
}

\author{
Joseph M.J. Renwarin \\ Institut Teknologi dan Bisnis Kalbis Jakarta Indonesia \\ Email:mrjoseph017@yahoo.com,joseph.renwarin@kalbis.ac.id
}

\begin{abstract}
The occurrence of the gap phenomenon between Indonesia's economic growth and population has increased but the retail market has declined. Therefore, the purpose of research is to find out how much the relationship between sales promotions and customer satisfaction in Matahari stores. The research method uses a quantitative approach with accidental sampling method through the distribution of questionnaires to 100 retail customers. The result of this research is the relationship between sales promotion and increasing customer satisfaction. The management should focus on midnight sale and member membership because it has a significant impact on customer satisfaction. The voucher discount variable and buy two get one free have not significant on customer satisfaction. In the next future, the research focuses on the increase of online shore sales promotion.
\end{abstract}

Keyword: Retail Customer, Customer's Satisfaction, Sales Promotion.

\section{INTRODUCTION}

Rapid economic growth in Jakarta is increasingly wide open for entrepreneurs to be able to develop their businesses and earn profits. One of the very rapid growths in Jakarta is the increasing number of Malls (Shopping Centers) due to the busy life of the people of Jakarta with their routines as employees or as entrepreneurs. They do not have much time to unwind going out of town or going to a place of recreation in Jakarta. Other factors also like congestion that cannot be avoided. Jakarta is touted as the city with the most malls in the world. Until 2010-2013 the number of malls in Jakarta reached more than 170. It is mentioned that in 2009 the number was only 130 and in 2008 the number was only 90 (Apipudin, 2014). There will still be 6 more malls to be built in Jakarta. On the other hand, the authors found data that there was a decline in the retail business. There is a drastic decline especially in May to June 2018. July to August 2018, it started rising but fell back in August to September 2018. Researchers also received data from Ceicdata.com that the decline in Retail Sales was $6.1 \%$ for 2018 . The growth in the land retail of water industry has recently slowed down due to several reasons. The factors that caused the slowdown included the economic conditions of the lower middle class and the shift in consumption patterns to leisure, as had been predicted since last year. Another reason is that the wave of industrial revolution 4.0 has had a major impact on the retail industry in Indonesia. There is a shift in urban society from offline shopping patterns to online shopping. This has a direct negative impact on the company's performance and causes many problems in the company. One of them is the problem of termination of employment (Laid off). Which is 
of concern to the author that how does the management of retail companies make effective marketing strategies so that retail businesses can grow again?

The result of observations were carried out in the era of $2017-2018$ where at this time Matahari department store closed several outlets stores. Many sales promotion programs carried out by the store department, such as: giving discounts, member members, discount vouchers and much more. The author sees that Matahari Department Store management continues to make various ways through retail strategies and other benefits that management can provide to customers. The author makes a research question, such as how much influence does the sales promotion have on Customer Satisfaction? How can knowing and analyzing sales promotions affect Customer Satisfaction?

The research gaps obtained by (Hamdani and Zaman, 2017) conducted a study on customer satisfaction at Pizza Hut Jakarta where their result showed that customer satisfaction was influenced by sales promotions. The same research and resulted which was conducted by (Azka, 2017) on the satisfaction of Traveloka consumers in Bandung. But on the other hand, the result of research from (Roring, 2015) stated that promotion does not affect the customer satisfaction of the Manado Grace Inn hotel. In line with the research carried out by (Fardiani, 2013), the study was conducted on consumers of Honey Ain in Bogor to find out the relationship between promotion and customer satisfaction at the cake shop, it was found that not all customers were satisfied with the sales promotion given, because the forms of promotion given were different, customers who got a small form of promotion were still not satisfied, when there were other customers who get a bigger form of sales promotion. Because the relationship is low, there is no relationship between sales promotion and customer satisfaction. The form of sales promotion should be able to attract customers to buy and feel satisfaction, and the form of sales promotion that is given should be evenly distributed to all customers, but in fact, not all customers feel the form of sales promotion, and do not make them satisfied, so there is no tendency that the higher the sales promotion carried out, the higher customer satisfaction. The absence of a relationship between sales promotion and customer satisfaction is also evidenced by the Rank Spearman correlation test. Based on the results of the correlation test obtained a sigma value that is equal to 1,000 , where the sigma value is greater than 0.05 , which means there is no relationship between the two variables. While the correlation coefficient of 0.000 means that there is almost no correlation between the two variables. It happens because not all customers get a sales promotion. In this study only a portion of the customers studied were promoted. It is because the customers who get promotions are only customers who frequently make purchases or make regular purchases. Some customers stated that they are from out of town and take a long time to get to the location, so some of them expect to get a form of sales promotion, but because they do not make large purchases, they do not get any kind of sales promotion, according to customers, the price offered is quite expensive, hence they do not make large purchases. Another study is that promotion is also one of the elements that has a relationship that is not in the same direction and very weak with the satisfaction of consumers Grow Cafe Malang, it is also supported that the average rating conducted by consumers showed a negative response to the element of promotion at Grow cafes that have average value the answer score is in the disagreeable position (Susila et al., 2017). The result of the study is supported by research conducted by (Wowor, 2013) which has resulted, that the promotion 
element does not partially affect the satisfaction of the consumers of Toyota Avanza Veloz PT. Hasjrat Abadi Manado.

The author gets a gap theory where some books see that promotional activities are to increase consumer satisfaction. Differ only from a doctoral dissertation was written by (Jetta Kurt, 2015) means that promotional activities are in addition to marketing activities in order to maintain relationships with customers. There are also those who have said that sales promotion is a marketing activity that proposes the added value of a product (to get more than what is available from the product value) in a certain period of time in order to encourage consumer purchases, sales effectiveness, or encourage efforts made by the sales force (Hermawan, 2012). There are also those who have said that sales promotions, companies can attract new customers, influence their customers to try new products, encourage customers to buy more, attack competitors' promotional activities, increase impulse buying (purchases without prior plans), or seek closer cooperation with retailer. (Herde and Neslin, 2017) mentioned that sales promotions are focused on finding consumers or long-term customers. The program used by the company is price promotion. The author sees that there is contra theory in which there is a stream that sees that promotion activities are aimed at short-term activities even when they are impromptu while there are also streams that see sales promotion activities to determine business continuity. The gap theory is also found in customer satisfaction. There is an opinion by (Tartaglione et al., 2019) that customer satisfaction is a driver for increasing customer loyalty whereas according to (Dinesh et al., 2018) that retail customer satisfaction is a form of survival, especially the threat of online stores.

\section{THEORITICAL REVIEW}

Customer Satisfaction. Customers as everyone who demands the company to meet certain quality standards and therefore will affect performance (Gaspersz, 2011). Many researchers make research with various perspectives on customer satisfaction. It happens because of differences in the unit of analysis or object of research and interest in the phenomenon that occurs. But the point is about the expectations of consumers after buying a product or service is in accordance with the value or value proposition. (Kotler and Keller, 2008) looked at another dimension of satisfaction, namely pleasure and disappointment. To make customers feel special, retailers need to make a difference with other companies. Customer satisfaction is very important to maintain existing customers. Satisfaction is a valuable experience because it exceeds expectations. Reciprocally, if the customer is not satisfied means that the customers do not expect what they wanted. If customers are satisfied, it forms customer loyalty, lowers costs, increases image and increases business performance (Boon and Rompho, 2012). Customer satisfaction can generate purchases continuously where it is the same as buying other products at the same company or the same shop (Quintal et al., 2017; Kim et al., 2019). Customer satisfaction and service quality are very important concepts, especially in a competitive environment that relies on several competitive advantages. Customer satisfaction has a positive impact on the profitability of the organization (Angelova and Zekifri, 2012). In addition to profitability, customer satisfaction also has an impact on company growth (Bruwer and Li, 2017). 
The level of customer satisfaction is usually increased when they shop and the availability of goods and services needed at that time effectively. Retailers usually carry the one stop shop concept (Enaworu et al., 2018). Similar to the behavior of customers in the retail industry, maintaining customers is not always determined by customer satisfaction (Selnes, 2013). This is reinforced by several studies conducted on how to retain potential customers (Mittal and Kamakura, 2016). Another study also shows that there is no influence from customer satisfaction when there is a cross -buying process (Verhoef, 2013).

Relationship Marketing. The idea of how to carry out activities in establishing harmonious relationships with customers has been introduced since the early 1990s. This idea of becoming companies gets better profits when the gap in relations is getting smaller between company relations and customer respect. In that era, the company realized that getting back existing customers and getting new customers needed more effort. Relationship Marketing is used as a tool to create marketing activities and programs in gaining respect from customers. These marketing activities and programs will bring together consumer expectations. Satisfaction and retention of consumers is usually seen as the most vital in maintaining a sustainable and long-term business (Enaworu et al., 2018). Market perception directs that there is a repurchase or intends to buy back from the customer. So, managing relationships with customers must be the full attention of retail management.

Another thing in maintaining relationships with customers is through the internet network. Sales promotion through the internet offers many variations of activities to stimulate market demand from customers generate high buying interest and facilitate purchases using computers or smartphones and other gadgets. Technology network is to spread information about goods and services through virtual markets (Jiang and Junhai, 2018). With the development of technology, internet sales promotion has become the main promotion strategy for business management. This is a positive activity in promotional programs and can increase sales. Internet sales promotion has several advantages over traditional sales promotions. Hence, it is forced that the right promotion to the right buyers, break through the limits of time and space and distance and spread throughout the world in that period of time.

From these opinions, the author takes several important notes that customer satisfaction has several levels and is very dependent on what the customer feels. Starting of being dissatisfied and satisfied is exceeding expectations. If the customer feels satisfied and even exceeds expectations, the company succeeds in creating value for the customer. This will result in the company's win in an atmosphere of competitive competition even in a state of intense competition. This is the importance of creating value for customers. Customer satisfaction is important to improve the customer-focused products and services. If consumers feel satisfied, they make an important contribution to the profitability of the company. In this journal, researchers use the dimensions of service quality produced by the Matahari department store with three main indicators to obtain field data, namely; Firstly, the products offered follow the times. Second, consumers are satisfied with the quality of the products offered. Third, consumers are satisfied with the completeness of the products offered. Fourth, feeling satisfied with the facilities of the store. 
Sales Promotion. Sales promotions can offer many benefits for customers, not only in terms of savings but also motivating to express the benefits enjoyed and sometimes are their own entertainment for customers (Kwok and Uncles, 2015). These benefits classify hedonic behavior from customers in the future. These benefits are very real for customers. Customers will maximize spending, make efficiency and economically. In general, with the sales promotion, hedonic behavior will provide a very meaningful experience for customers because it is usually a condition where if customers can get the most out of the shopping material from a promotional event, the customer will feel happy and like being out for sightseeing. The pattern of sightseeing and holidays for Indonesians is shopping even though sometimes it is not a necessity. The benefits obtained are the benefits of hedonic.

Promotion is emphasized on activities such as advertising, sales, and more specifically, an explanation of sales promotions to consumers about products and services (Ruiz et al., 2010). One of the marketing programs in maintaining customer relationships is a sales promotion program. Retailers need a tool to stimulate buyers to make purchases/ transactions faster the tool is a sales promotion. Sales promotion includes one of the elements of the promotion mix that is on one of the promotional factors. Stimulatingly, consumer purchases through marketing campaigns (Kotler and Keller, 2009). In direct persuasive forms, it attracts new customers, influencing customers to try new products, encouraging customers to buy their products more than usual, attacking competitors' activities, increasing unplanned purchases (Hermawan, 2012). Retailers provide further stimulation with various forms of sales promotions such as: sale/ discount prices, discount vouchers, buy two get one free, membership, lottery. Many creative ways are carried out by retailers in conducting sales promotions (Sopiah and Syihabudhin, 2008). Sales promotion is designed to differentiate different target destinations and markets, namely retailers, merchant agents and customers (Blattberg and Briesch, 2012; Samsi and Khan, 2017). Direct sales promotion tools through re-sellers (distributors, retailers, wholesalers, etc.) with a number of conditions. Usually the tools used are discounted, free samples, contests, bonuses, premiums, in-store displays, etc. besides invoice allowances, free goods, buy-back allowances, contests, etc. that are very common in transactions this retail. For manufacturing, sales promotion programs use pull strategy to stretch customers and motivate them to make repeated purchases. The company pays attention to the level of customer satisfaction because more and more free space for customers to express complaints and dissatisfaction throughout the world through social media and the internet. In this journal, researchers use several dimensions to obtain field data, namely; First, the Midnight Sale Program with three indicators for each midnight sale is held at the end of each weekend, how to buy interest during midnight sale and discount programs at midnight sale. Second, event promotion with notification indicators via newspapers, online media, radio. Third, Discount Vouchers with indicators of warehouse washing programs, holidays, direct prizes without draws, special products without draw for Rp. 150,000 and guess quiz prizes for vouchers. Fourth, a by one get one free program with indicators only for special products, branded products, point reward systems. Fifth, membership with a one point indicator is for referrals, merchant discounts. Sixth, lottery with year-end lottery indicators will be simultaneous lottery, lottery coupons. From this opinion, the researchers see that all promotional activities will satisfy consumers because 
they exceed expectations. So the researcher hypothesized that there was an effect of retail sales promotion on consumer satisfaction. The author formulates the following:

Ho: There is no relationship and influence between sales promotions and customer satisfaction.

Ha: There is a relationship and influence between sales promotion and customer satisfaction.

\section{METHODOLOGY}

The method used in this study is the exploration method using a quantitative approach. This study uses a quantitative linear research type, starting from clear research steps through problem formulation, research objectives, fundamental theories, hypothesis development, research methods, data collection techniques, data analysis, drawing conclusions and giving suggestions for next researcher (Ruslan, 2010). This study also uses survey methods through several statements in the form of questionnaires and responses or statements of respondents both verbally and in writing (Anwar, 2013).

Because the population type in retailing is the most uncountable population, the sampling technique used is accidental technique, which is all respondents who accidentally met during data collection and shopping (Gozali, 2011). Data sources are primary data obtained through questionnaire distribution in three different outlets namely Matahari Department outlets in three shopping centers such as Taman Anggrek, Citraland and Gajah mada Plaza. The author sets 100 consumers as, with details of 50 respondents from Taman Anggrek, 15 Citra Land and 35 respondents from Gajah Mada is used as respondents. In quantitative research, the data analysis technique that will be used is clear, namely by being directed to answer the formulation of the problem or test the hypotheses that have been formulated. Because the data is also quantitative, the data analysis technique uses statistical methods. In this case, the data is processed using software that has been installed on the computer, namely the SPSS program (statistical package for social science) ver.12. The data analysis tool that will be used is the validity test and reliability test. In this study, each dimension was tested one by one using factor analysis techniques so that Kaiser-Meyer-Olkin (KMO) value will be obtained, which is a statistical test used to show the accuracy of factor analysis of the measured variables. If the value of KMO $>0.500$ with a significance value of $<0.05$ then the variable can be measured using factor analysis techniques to determine whether the indicators made are indeed in one group with other indicators that are still in one variable. To test the reliability of the instrument by using Alpha Cronbach technique by testing one dimension. The standard $X$ value used to indicate that the gauge will be good if $>0.500$. So the closer it is to 1.00 , the questions listed are more reliable and if the results obtained are below 0.500 , the measurement can be said to be unreliable.

For regression tests performed to display the value: (1)The value of significance of the Multi-way Analysis of Variance (ANOVA) Univariate is $<0.05$, to see the influence of the dependent variable with the independent variable. (2)Value of $\mathrm{R}$ summary model, to see the strength of the relationship between the independent variable and the dependent variable (3)The value of R Square in the summary model, which shows the percentage of 
the ability of uniformity (variance) that, is owned by the independent variable. (4)Beta value which shows the contribution of each independent variable to the dependent variable.

To test the effect of each dimension, the author uses the coefficient table where the result of the t-test result is analyzed compared to t-table. Hence, the multiple regression tests, still using the result of the coefficient table processed with the SPSS program.

In addition to the primary data, the author also took secondary data from the previous literature and some data from various online media.

From the description of the theory, the authors make a model for this study as follows.

\section{Research Model}

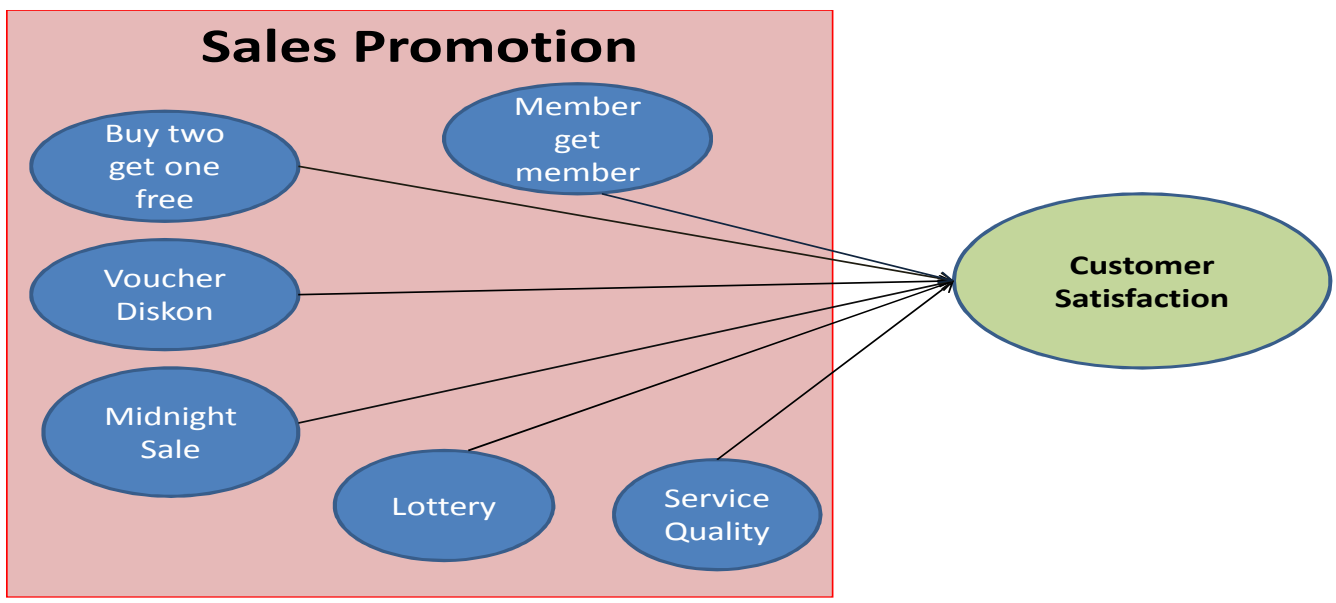

Figure 1. Research Model

Source: author's result based on phenomena, 2017

\section{RESEARCH RESULT AND DISCUSSION}

Result of Validity test as in the following table:

Table 1. Test Validity

\begin{tabular}{lccc}
\hline $\begin{array}{c}\text { Dimension of } \\
\text { variables }\end{array}$ & KMO & $\begin{array}{c}\text { Bartett'stest of } \\
\text { sphericity }\end{array}$ & $\begin{array}{c}\text { Total covariance } \\
\text { explained (\%) }\end{array}$ \\
\hline Midnight Sale & 0,759 & 0,000 & 85,157 \\
\hline Discount Voucher & 0,797 & 0,000 & 84,216 \\
\hline Buy one get one free & 0,500 & 0,000 & 83,351 \\
\hline Member get member & 0,715 & 0,000 & 96,235 \\
\hline Lottery & 0,670 & 0,000 & 82,915 \\
\hline Service Quality & 0,773 & 0,000 & 73,165 \\
\hline
\end{tabular}

Source: (processed products with SPSS, 2017) 
From table 1 it can be seen that the dimensions of the variable are said to be valid because they meet the requirements of KMO (Keyser Meyer Oalkin), which is above 0.500 with a significance of 0,000 and total covariance explained at $60 \%$. If a variable with a KMO value above 0.500 means that the variable or dimension is feasible to be included in the subsequent data processing. Vice versa, if the dimensions or variables tested under 0.500 means invalid to continue. Based on the table above, it can be seen that all indicators of these dimensions are valid and worthy of further testing.

Reliability test results show results like the following.

Table 2. The Result of Reliability test

\begin{tabular}{lcc}
\hline \multicolumn{1}{c}{ Dimension of variables } & Cronbach'sAlpha & N of Items \\
Midnght Sale & .937 & 4 \\
\hline Discount Vouchers & .925 & 4 \\
\hline Buy One get one free & .765 & 3 \\
\hline Member get member & .980 & 3 \\
\hline Lottery & .891 & 3 \\
\hline Service Quality & .860 & 4
\end{tabular}

Source: (processed products with SPSS, 2017)

Dimension or variables measured can be stated to be reliable if they fulfill the requirement that the value of the calculation results must be equal to or above the value of Cronbach's Alpha 0.500. From table 2, it can be seen that all Cronbach's Alpha values from each measured dimension show values above 0.500 so that it can be said that these dimensions are reliable and can be used for subsequent data processing.

To detect whether these indicators are normal, a normality test is used by using the Kolmogorov-smirnov statistical test. The provisions that must be fulfilled are as follows.

- If the significance value $=0.05$ is normally distributed

- If the significance value> 0.05 is not normal distribution

The result of the normality test are as follows:

Table 3. One Sample Kolmogrov-Smirnof Test

\begin{tabular}{llrr}
\hline & & \multicolumn{1}{c}{$\begin{array}{c}\text { Sales } \\
\text { Promotion }\end{array}$} & $\begin{array}{c}\text { Customer } \\
\text { Satisfied }\end{array}$ \\
\hline $\mathrm{N}$ & & 35 & 32 \\
\hline Normal & Mean & .5319 & .4914 \\
\hline Parameters (a,b) & Std Deviation Absolute & .25300 & .30440 \\
\hline Most extreme differences & & .335 & .143 \\
\hline & Positive & .208 & .134 \\
\hline & Negative & -.335 & -.143 \\
\hline Kolmogrov-Smirnov & & 1.981 & .845 \\
\hline Asymp Sig (2-tailed) & & .001 & .473
\end{tabular}


a. The distribution test is normal

b. Calculated from data

Source: (Processed products with SPSS, 2017)

From the data of the result the normality test in table 3 , it showed that the Kolmogrov-Smirnov value in the Sales Promotion variable is 1.981 with a significance of 0.001 . This showed that the variable of giving sales promotion is normally distributed because the significance value is $<0.05$. Therefore the Customer Satisfaction variable is abnormally distributed, because the significance value is $>0.05$.

The Hypothesis test is to find out whether the Sales Promotion variable affects Customer Satisfaction obtained data that with a margin error rate of 0.05 get a result of 2.030 and significant. This means that sales promotions have an influence on customer satisfaction because the value of $t$ count is 2.030 greater than table $t$ of 1,000 . The table of hypotheses is outlined in table 6 . But before that the writer performs the procedure to go to the table of result of hypostasis statistical.

Next, the author conducted a determination test as follows.

Tabel 4. Model summary

\begin{tabular}{ccccc}
\hline Model & R & R Square & $\begin{array}{c}\text { Adjusted R } \\
\text { Square }\end{array}$ & $\begin{array}{c}\text { Std Error of } \\
\text { the estimate }\end{array}$ \\
\hline 1 & .972 & .944 & .941 & .24287388 \\
\hline
\end{tabular}

Source: (Processed products using SPSS, 2017)

From the result of data processing it was found that the relationship between the independent variables, sales promotion as the independent variable and customer satisfaction as the dependent variable, was $97.2 \%$. It is shown that it has a positive relationship. While the influence of Sales Promotion on Customer Satisfaction is $94.4 \%$, meaning 5.6\% indicated that Customer Satisfaction is not only influenced by Sales Promotion, but by other factors.

Tabel 5. ANOVA

\begin{tabular}{llrrrrrr}
\hline Model & & \multicolumn{1}{c}{$\begin{array}{c}\text { Sum of } \\
\text { Squares }\end{array}$} & df & Mean Square & F & \multicolumn{1}{c}{ Sig } \\
\hline 1 & Regression & 93.455 & 5 & 18.691 & 316.863 & .000 \\
\hline & Residual & 5.545 & 94 & .059 & & \\
\hline & Total & 99.000 & 99 & & & & \\
\hline
\end{tabular}

Source: (Processed products using SPSS, 2017)

Based on statistical calculations obtained the result from calculations on the ANOVA model, Sales Promotion has an influence on customer satisfaction. This is indicated by a significance value below 0.05 , which is equal to 0,000 , meaning that the influence between the two variables in this study is significant. 
This showed that Ho stated that there is no relationship and the influence of Sales Promotion on customer satisfaction is rejected because the results of the study show that the significance value of the Sales Promotion variable is below 0.05 so Ho is rejected.

Thus Ha which stated the existence of a relationship and the influence between Sales Promotion on customer satisfaction is accepted. This showed that the dimensions that exist in the Sales Promotion variable, namely discount sales, discount vouchers, one free buy two program, member get member and lottery do have a relationship and influence with the dependent variable, namely customer satisfaction.

The researcher tested the influence of each dimension on customer satisfaction by issuing service quality from this test. The main reason is that the sales programs will be evaluated in the form of sales promotions currently offered by Matahari department store. The result is obtained as in the following table.

Tabel 6. Coefficients

\begin{tabular}{|c|c|c|c|c|c|c|}
\hline Model & & $\begin{array}{l}\text { Unstandardized } \\
\text { Coefficients }\end{array}$ & & $\begin{array}{l}\text { Standardized } \\
\text { coefficients }\end{array}$ & $\mathbf{t}$ & Sig \\
\hline 1 & & $\mathrm{~B}$ & $\begin{array}{l}\text { Std } \\
\text { Error }\end{array}$ & Beta & & \\
\hline \multirow[t]{6}{*}{1} & Constant & .000 & .024 & & .000 & 1.000 \\
\hline & Midnite Sale & .995 & .490 & .995 & 2.030 & .045 \\
\hline & $\begin{array}{l}\text { Discount } \\
\text { Voucher }\end{array}$ & -.071 & .132 & -.071 & -.538 & .592 \\
\hline & $\begin{array}{l}\text { Buy two get } \\
\text { One free }\end{array}$ & .048 & .050 & .048 & .978 & .331 \\
\hline & $\begin{array}{l}\text { Member get } \\
\text { member }\end{array}$ & .622 & .270 & .622 & 2.307 & .023 \\
\hline & Lottery & -.604 & .726 & -.604 & -.832 & .408 \\
\hline
\end{tabular}

a. Dependent variable customer satisfaction

Source: (Processed products using SPSS, 2017)

From the table 6 the coefficients can also be carried out in a nominal analysis of only midnight sale which has a significant effect of 2,030 and member get members of 2,307 . For discount vouchers, buy two get one and lottery, there is no significant and no effect on customer satisfaction. This could be the first element of novelty in this study where tracing of previous theories and literature states that sales promotion programs affect customer satisfaction. But the fact of this article is that not all elements of sales promotion affect customer satisfaction in Indonesia.

From table 6 it is also seen that the business model illustrated through a linear equation is $\mathrm{Y}=\mathrm{a}+\mathrm{b} 1 \mathrm{X} 1+\mathrm{b} 2 \mathrm{X} 2+\mathrm{b} 3 \mathrm{X} 3+\mathrm{b} 4 \mathrm{X} 4+\mathrm{b} 5 \mathrm{X} 5+\mathrm{e}$. If it is interpreted in this journal, based on the coefficient table, the regression equation is obtained. 
Customer satisfaction $=0.000+0.995$ Midnite Sale -0.71 Voucher Discount +0.48 Buy two Get One Free + 0.622 Member get Member - 0.604 Lottery.

\section{Illustration of this model.}

First, that every addition of one midnite sale unit, buy one get one free and member get member will increase customer satisfaction. Moreover, vice versa, if a discount voucher and lottery increase by one unit will reduce customer satisfaction.

Second, the constant value of 0.000 indicates that the importance of Matahari Department Store management pays attention to factors such as Midnight Sale, buy two get one free, member get members, discount vouchers, and lottery as an implementation strategy outlined in annual work programs, because if the company not paying attention to these factors, there is no customer satisfaction (as evidenced by the statistical number 0.00 ).

Third, if the management of the Matahari Department Store company will implement the strategy, the first priority is the Midnight Sale program because it gives the highest beta coefficient value of 0.995 or $99.5 \%$. The next program is member get member because it has a coefficient of 0.662 or $66.2 \%$. The most recent program is buy two get one free because it only gives a value of 0.48 or $48 \%$ towards increasing customer satisfaction.

Fourth, the management of the Matahari Department Store Company must also take into account the factors that cause a decrease in customer satisfaction. The first factor that must always be monitored from a marketing work program is the provision of discount vouchers where the beta coefficient value that shows customer dissatisfaction is 0.71 or $71 \%$. Likewise with the lottery program, the beta value coefficient is almost the same, which is 0.604 or around $60.4 \%$.

The result of the linear regression test also provide a second novelty in the result of this study. Lottery vouchers and lotteries actually make customers more dissatisfied with retail businesses in Indonesia.

\section{CONCLUSION}

Based on the result of research conducted by researchers, the conclusions that can be made are as follows. The occurrence of gaps is a phenomenon where the mall grows while the retail industry which is the backbone of the mall shows a decline in performance, the gap in research results and the gap of current theories. Wave 4.0 makes consumer spending patterns shift from offline shopping to online shopping. The result of the study stated that this study proved $100 \%$ valid. In terms of reliability, the number 0.944 is obtained, which means that this number is between the numbers exceeding 0.500 , so this research is reliable or reliable. Answering the research question about the relationship between Sales Promotion and Customer Satisfaction, then obtained a correlation number of 0.972 . This means that the variable relationship is strong. Positive correlation indicates the existence of a unidirectional relationship between the two variables. That is, if there is an increase in sales promotions, then customer satisfaction will increase as well. The 
magnitude of the influence of sales promotions on customer satisfaction is that of $94.4 \%$. Customer satisfaction can be greatly influenced by sales promotions. The rest, which is $5.6 \%$, must be explained by other factors, such as information delivered starting from the language style, the media used, the intensity of advertising as a marketing tool / strategy, human resources from the Matahari Store Department. Store and so on. The preliminary analysis of only midnight sale has a significant effect of 2,030 and member get member is 2,307 . For discount vouchers, buy two get one and lottery, there is no significant and no effect on customer satisfaction. The factors that led to an increase in customer satisfaction were Midnight Sale, buy two get one free and member get member. Factors that can cause a decrease in customer satisfaction are discount vouchers and sweepstakes.

Theoretical Implications. The meaning contained in this journal is to investigate factors that cause customers to be satisfied through the dimensions of Matahari sales promotion department stores in three different locations but almost have similar characters. In line with this study conducted by (Ubeja, 2014), who researched shopping at the mall. They identified many factors from the sales promotion mix. They identified 18 factors from the sales promotion mix to measure customer satisfaction shopping at several malls. With the help of several analysis factors such as in this journal, they found that five factors such as lucky and bumper, frequent and guaranteed monetary benefits, gift and exchange, and finally discount offers. In addition, their target market is millennial buyers who usually hang out at the mall to spend time after college or school. With an attractive sales promotion, it will get potential new buyers. Shopping is a fun activity for young people. So they will be happy to pay attention to sales promotions at the mall. As is the case with malls in Indonesia that visiting malls for millennial and young people is fun. Sometimes they only come to eat, drink coffee, watch movies in theaters and often buy clothes at certain outlets and have a good reputation.

The result of this study is also in line with research from (Park Jin-Woo et al., 2013). The research location is at the Korea Airport. The factors used are cutting price, cent off, point accumulation, and free gift. Although there are differences in the names of dimensions but this research has the same meaning and phenomenon. Promotion proved to have a positive and significant effect on customer satisfaction, which can be seen from the test $-t$ of 3.818 with sig. $0,000<\alpha=150.05$. The positive value obtained shows that the higher the promotion carried out by Gardenia Fitness Center in Semarang it will increase customer satisfaction (Munandar, 2016). Promotion is communicating information between sellers and potential buyers or other people to influence attitudes and behavior (Cannon et al., 2011). Promotion carried out continuously shows the desire of sellers to compete and have the ability in quality to meet consumer needs, so that this makes consumers users feel satisfied when using products or services offered.

Managerial Implications. The managerial implications which are suggestions that the author can provide relating to this research are: (1)The sale program offered by the department store Matahari must be more attractive and different from other department stores, such as the "marathon sale" program. This program offers discounts of up to $80 \%$ starting from 22.00 - 10.00 the next day. (2)Discount vouchers given by department store sun must have considerable value, such as when consumers shop for Rp. 500,000, - the 
Matahari department store provided a voucher worth Rp. 150,000, - with a minimum shopping of Rp. 300,000, - for spending the following day. (3)In a free one-party buy two promotion program Matahari department store must add new products offered to be more varied and add many choices to give satisfaction to customers. (4)In the member program can be implemented the member get member program where each customer who has a member can invite other customers to become members in accordance with the applicable provisions by getting a direct prize (5)In the lottery program to be more attractive, department stores must innovate by seeing the phenomenal - phenomenal that happened at that time, for example by shopping for Rp. 1,000,000 will get lottery coupons with the latest smartphone prizes at the end of each month. It is a trend nowadays that smartphones are in great demand by the general public and want to have them so that they can be used as a reference.

Methodological Implications. Implications of research methodology is to discuss the ways and methods of the theories used in a study. The author makes several methods in discussing research problems. The case of declining buying interest and repurchasing decisions on retail businesses, especially Matahari Department Store, is rather difficult to discuss with a theoretical approach, especially the determination of the dimensions of the variables that have been chosen. The method used in this study is to look at sales promotion programs carried out in three outlets that are the object of research. This method is expected to be a reflection of the authors of the results of the study. This is understandable because each researcher must have a unique way and each method to complete the results of his research, especially for problems that are crucial.

In the overall result of the study, there must be a method that is difficult to do and that is easy to apply. So from that methodology implications aim to explain the difficulties and challenges experienced by researchers during completing the result of these studies. Nonetheless, the author still finds international journals that do use field programs that are used as dimensions of predetermined variables.

In addition, the methodological implications also explain innovations and what ideas have been found, developed and carried out to solve a problem in science through the results of research. The aim of always conducting research on an ongoing basis is to improve and refine the scientific findings. The more perfect the results of the study, the better the quality of the research itself can be a resolution for the problems that exist in the study of science. The author poured innovative ideas from the findings in the study, namely the regression model where there are two dimensions namely lottery programs and discount vouchers. In addition, even though in testing t, researchers use service quality variables, but to make a path test through linear regression, the researcher does not include the dimensions of service quality on the grounds to further deepen the analysis of the findings.

Suggestions For Future Researchers. The author has limitations in this study. The author only uses the sales promotion factor to measure customer satisfaction. The author sees that factors such as store atmosphere, design layout, ambiance can also be used to measure how much consumers feel satisfied as further research. How closely is this relationship between variables and customer satisfaction. Further research can also be 
directed in terms of sales promotion programs that influence the buying interest through online compared to the offline concept because of the current situation of the emergence of online shops. It could also be research on sales promotion in dealing with customer complaints so that customer satisfaction increases. Researchers also hope that further research can be carried out research on other samples and pollutants outside the retail such as manufacturing industries, services and others.

\section{REFERENCES}

Angelova B dan Zekifri J, (2012). Measuring Customer Satisfaction with Service Quality Using American Customer Satisfaction Model (ACSI Model). International Journal of Academic Research in Business and Social Sciences October 2011, Vol. 1, No. 3 ISSN: 2222-6990. DOI: 10.6007/ijarbss.v1i2.35.

Anwar, Sanusi. (2013). Business Research Methodology. Third print. Salemba Empat Publisher, Jakarta Indonesia.

Apipudin, (2014). Brand Switching Analysis dalam Industri Ritel Modern, Artikel Riset, marketplus.co.id

Azka Z N, (2017). Pengaruh Promosi dan Kualitas Pelayanan Dalam Belanja Online Terhadap Kepuasan Konsumen Traveloka, Jurnal Universitas Pasundan Berry, L. L., Seiders, K., \& Grewal, D. (2012). Understanding service convenience. Journal of Marketing, 66(3), 1-17.

Boon-itt, S., and Rompho, N. (2012). Measuring Service Quality Dimensions: An Empirical Analysis of Thai Hotel Industry. International Journal of Business Administration, 3(5), 52-63 DOI: 10.5430/ijba.v3n5p52.

Bruwer, J., and Li, E. (2017). Domain-specific market segmentation using a latent class mixture modeling approach and wine-related lifestyle (WRL) algorithm. European Journal of Marketing, 51(9/10), 1522-1576.

Cannon, Joseph P., William D. Perreault Jr. dan Jerome McCarthy. (2011). Alih Bahasa : Diana Angelica dan Ria Cahyani. Pemasaran Dasar-Dasar : Pendekatan Manajerial Global. Buku 2. Edisi 17. Salemba Empat. Jakarta.

Dinesh. P, Norida.A, Ali.H.M.R (2018). Customer Satisfaction and Retention Towards Retail Store In Malaysia. International Journal of Human and Technology Interaction, ISSN: 2590-3551 eISSN: 2600-8122 Vol. 2 No. 2.

Enaworu, E., Adegboye, F. B., and Wara, H. U. (2018). Competitiveness in Banking Industry: A Study of Employee Satisfaction, Customer Satisfaction and Productivity in Service Quality. Competitiveness in Emerging Markets, Springer 373-390. doi:10.1007/978-3-319-71722-7_19.

Fardiani, Aprillia. (2013). Analisis Pengaruh Kualitas Pelayanan, Harga, dan Promosi Terhadap Kepuasan Pelanggan Dyriana Bakery \& Café. Universitas Diponegoro, http://eprints.undip.ac.id/38724/1/FARDIANI.

Gaspersz, Vincent. (2011). Total Quality Management: Untuk Praktisi Bisnis dan Industri . Vinchristo Publication: Bogor.

Ghozali. Imam. (2011). Analisis Multivariate dengan Program SPSS. Semarang: Badan Penerbit Universitas Diponegoro. 
Hamdani N. A dan Zaman M A, (2017). Pengaruh kualitas pelayanan dan promosi terhadap kepuasan konsumen pada Pizza Eexpress Jakarta. Jurnal Wacana Ekonomi. Universitas Garut.

Heerde, H.J. van and Neslin, S.A (2017), Sales Promotion Models, Handbook of Marketing Decision Models, International Series in Operations Research \& Management Science 254, DOI 10.1007/978-3-319-56941-3_2 () Springer International Publishing AG.

Hermawan A (2012). Komunikasi Pemasaran. Jakarta: Erlangga.

Jetta Kurt, (2015), A Theory Of Retailer Price Promotion Using Economic Foundations: It's All Incremental, Research Dessertation, Fordham University

Jiangan Hui dan Ma Junhai, (2018), Effects of Internet Sales Promotion on a Differential Advertising Model, Discrete Dynamics in Nature and Society, Volume 2018, Article ID 8618146, 11 pages https://doi.org/10.1155/2018/8618146.

Kim W O, Cho J L , and Kim K S, (2019). The relationships of wine promotion, customer satisfaction, and behavioral intention: The moderating roles of customers' gender and age, Journal of Hospitality and Tourism Management, https://doi.org/10.1016/j.jhtm.2019.03.001.

Kotler P dan Keller K L (2008). Manajemen Pemasaran Edisi 13 Jilid 1. Terjemahan Bob Sabran, MM. Jakarta: Erlangga.

Kotler P dan Keller K L (2009). Manajemen Pemasaran Edisi 13 Jilid 2. Terjemahan Oleh Bob Sabran, MM. Jakarta: Erlangga.

Kwok Simon and Uncles Mark (2015), Sales Promotion Effectiveness: the impact of consumer differences at an ethnic-group level. Journal of Product \& Brand Management, 170-186, Emerald Group Publishing Limited (DOI 10.1108/10610420510601049).

Martin, W. B. (2002). Quality Service. Pearson Education, New Jersey.

Mittal, V., and Kamakura, W. A. (2016). Satisfaction, repurchase intent, and repurchase behavior characteristics. Journal of Marketing Research, 38(1), 131-142.

Munandar L. A, (2016). Pengaruh Pelayanan, harga dan Promosi terhadap Kepuasan Konsumen yang berdampak pada Loyalitas Konsumen Gardenia Fitness Center di Semarang, Fakultas Ekonomi \& Bisnis, Universitas Dian Nuswantoro Semarang URL : http//dinus.ac.id/.

Park Jin-Woo, Choi Yu-Jin, Moon Woo-Choon, (2013). Investigating the effects of sales promotions on customer behavioral intentions at duty-free shops: An Incheon International Airport case study, JAIRM, 2013 - 3(1), 18-30 Online ISSN: 20144806 - Print ISSN: 2014-4865http://dx.doi.org/10.3926/jairm.18

Quintal V, Thomas B, Phau I and Soldat Z, (2017). Using push-pull winescape attributes to model Australian wine tourist segmentation, International Journal of Wine Business Research, Vol. 29 Issue: 4, pp.346-372, https://doi.org/10.1108/IJWBR-012017-0007.

Roring, (2015). Analisis Harga, Promosi, dan Kualitas Pelayanan terhadap Kepuasan Konsumen pada Hotel Manado Grace Inn, Jurnal Riset Ekonomi, Manajemen, Bisnis dan Akuntansi

Ruslan, Rosady. (2010). Public Relations and Communication Research Method. Rajagrafindo Persada publisher, Jakarta Indonesia. 
Ruiz-Molina M.E, Gil-Saura I and Berenguer-Conti G, (2015), Instruments for Wine promotion in upscale restaurants, Journal of Foodservice Business Research, pages 98-113, doi: 10.1080/15378021003784483.

Selnes, F. (2013). Antecedents and consequences of trust and satisfaction in buyer-seller relationships. European Journal of Marketing, 32(3/4), 305-322.

Shamsi Mohd Salman dan Khan Mohd Asif (2017), Sales Promotion Techniques and Consumer Behavior: A Case Study of Readymade Garments. Proceedings of ICRBS 2017.

Susila I G B, Rooswidjajani, Ratri A M, (2017), Hubungan Bauran Pemasaran dengan Kepuasan Konsumen (Studi Pada Konsumen Kafe Grow Malang), Jurnal Bisnis dan Manajemen Vol. 4 No.2, Juni 2017, p 165-171 p-ISSN : 1829-7528 e-ISSN : 25811584.

Tartaglione A M, Cavacece Y, Russo G and Granata G. (2109). A Systematic Mapping Study on Customer Loyalty and Brand Management, Adm. Science Journal; doi:10.3390/admsci9010008 www.mdpi.com/journal/admsci.

Sopiah dan Syihabudhin (2008) Manajemen Bisnis Ritel. Yogyakarta: C.V Andi Offset (Penerbit ANDI).

Ubeja Satnam K. (2014). A study of sales promotion Mix on customer satisfaction with reference toshopping malls in Gwalior City,GITAM Journal of Management, Vol. 72, No. 1, PP. 79-94.

Verhoef, P. C. (2013). Understanding the effect of customer relationship management efforts on customer retention and customer share development. Journal of Marketing, 67(4), 30-45.

Wowor V , R, (2013), Bauran Pemasaran Jasa, Pengaruhnya terhadap Kepuasan Konsumen Pengguna Mobil Toyota Avanza Veloz PT. Hasjrat Abadi Manado. Jurnal EMBA. 